\title{
体外循環における抗サイトカイン療法の臨床的検討
}

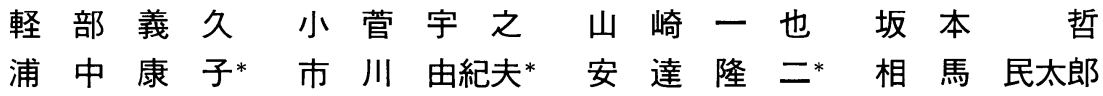

体外循環におけるウリナスタチンの抗炎症性サイトカイン効果と臓器障害軽減効果を検討した。冠状 動脈バイパス術施行 33 例をウリナスタチン投与群（UTI 群, $n=16$ ） と非投与群 (Control 群, $n=17 ） に$ 分け比較した。術中術後にインターロイキン $6($ IL-6) 8 8（IL-8）, 顆粒球エラスターゼ (PMNE) を測定した。 また肝臓（GOT, GPT, T-Bil), 腎臓（BUN, $\mathrm{Cr}$ ), 肺 $\left(\mathrm{PaO}_{2} / \mathrm{FIO}_{2}\right)$ の 術後機能障害を検討した。大動脈遮断解除 5 分後 IL-8 $(25.5 \pm 12.8 \mathrm{pg} / \mathrm{dl}$ vs. $47.8 \pm 38.9 \mathrm{pg} / \mathrm{dl})$, 経過中最高 IL-8 $(28.6 \pm 13.2 \mathrm{pg} / \mathrm{dl}$ vs. $58.4 \pm 40.0 \mathrm{pg} / \mathrm{dl})$, 術後 BUN, Cr が Control 群に比べ てUTI群で有意に低值を示した $(p<0.05)$. IL- 8, PMNEが BUN, Cr と正の相関, IL-8 と $\mathrm{PaO}_{2} / \mathrm{FIO}_{2}$ が負の相関を認めた。 ウリナスタチンの抗 IL-8 効果と IL-8，PMNE の抑制による術 後腎臓, 肺機能障害予防の可能性が示唆された。 日心外会誌 28 巻 3 号 : 151-157（1999）

Keywords : 体外循環, SIRS, 炎症性サイトカイン, 抗サイトカイン療法, ウリナスタチン

\section{Clinical Study of Anticytokine Therapy during Cardiopulmonary Bypass}

Norihisa Karube, Takayuki Kosuge, Ichiya Yamazaki, Akira Sakamoto, Yasuko Uranaka*, Yukio Ichikawa*, Ryuji Adachi* and Tamitaro Soma (Department of Cardiovascular Surgery, Saiseikai Yokohama City Nanbu Hospital, Yokohama, Japan and Department of Cardiovascular Surgery, Yokohama Minami Kyosai Hospital*, Yokohama, Japan)

Cardiac operations involving cardiopulmonary bypass can cause a systemic inflammatory response such as elevation of inflammatory cytokines, which can cause organ failure. We investigated cytokine production and its inhibition by ulinastatine in patients undergoing elective coronary artery bypass grafting under cardiopulmonary bypass. Thirty-three patients received either ulinastatine $(300,000$ units, intracoronary artery injection immediately after aortic clossclamping, UTI group, $n=16$ ) or no ulinastatine (control group, $n=17$ ). Arterial blood samples were obtained at aortic closs-clamping, 5 minutes after aortic declamping, and 6, 12 and 18 hours after surgery and there were assayed for interleukin-6 (IL-6), interleukin-8 (IL-8), and polymorphonuclear leukocyte elastase (PMNE). In addition, we examined liver function (GOT, GPT, and total bilirubin), renal function (blood urea nitrogen and serum creatinine), and oxygenatory function $\left(\mathrm{PaO}_{2} / \mathrm{FIO}_{2}\right)$ postoperatively. IL-8 levels at 5 minutes after aortic declamping and maximum IL-8 levels were significantly lower in the UTI group than in the control group (25.5 \pm 12.8 vs. $47.8 \pm 38.9 \mathrm{pg} / \mathrm{dl}, p<0.05$, and $28.6 \pm 13.2$ vs. $58.4 \pm 40.0 \mathrm{pg} / \mathrm{dl}, p<0.05)$. Blood urea nitrogen on the second post operative day (POD) and three POD and creatinine on the second POD were also significantly lower in the UTI group than the control group. Furthermore, IL-8 and PMNE levels significantly correlated positively with blood urea nitrogen and creatinine. There was significant negative correlation between IL-8 and oxygenatory function. These results shows that the ulinastatine can inhibit IL-8 levels following cardiac surgery. To combat the increase of inflammatory cytokines such as IL- 8 after cardiopulmonary bypass, the ulinastatine should be used for anticytokine therapy to protect the kidneys, lungs, and other organs, and thereby decrease the risk of complications. Jpn. J. Cardiovasc. Surg. 28: 151-157 (1999)

1998 年 4 月 21 山受付, 1998 年 12 月 24 日採用 済生会横浜市南部病院心臓血管外科 $\bar{T} 234-0054$ 横浜市港南 区港南台 3-2-10

*横浜南共済病院心臓血管外科

本論文0要旨は, 第 50 回日本胸部外科学会総会（1997 年 10

月, 東京）に扔いて発表した。
手術により過剰に産生された炎症性サイトカイ ンは本来防御するべき正常組織をも破壊する臓器 障害因子であり，また近年提唱されている SIRS (systemic inflammatory response syndrome: 全身性炎症反応症候群）の本質は高サイトカイン 
表 1 対象症例背景

\begin{tabular}{lccc}
\hline & UTI 群 & Control 群 & \\
\hline 症例 & 16 & 17 & $\mathrm{NS}$ \\
年齢(歳) & $61.9 \pm 6.5$ & $64.4 \pm 10.4$ & $\mathrm{NS}$ \\
性(男性: 女性) & $12: 4$ & $15: 2$ & $\mathrm{NS}$ \\
体外循環時間 $($ 分) & $153 \pm 53$ & $167 \pm 51$ & $\mathrm{NS}$ \\
大動脈遮断時間 $($ 分) & $89 \pm 28$ & $102 \pm 33$ & $\mathrm{NS}$ \\
バイパス数 $($ 本) & $2.2 \pm 0.4$ & $2.6 \pm 0.7$ & $\mathrm{NS}$ \\
最低直腸温 $\left({ }^{\circ} \mathrm{C}\right)$ & $30.9 \pm 0.9$ & $31.0 \pm 1.3$ & $\mathrm{NS}$ \\
最低食道温 $\left({ }^{\circ} \mathrm{C}\right)$ & $29.7 \pm 0.8$ & $29.1 \pm 3.3$ & $\mathrm{NS}$ \\
\hline
\end{tabular}

血症にあるとされている ${ }^{1,2)}$. 従って手術侵襲に より産生された炎症性サイトカインの適切な抑制 は生体の良好な回復と術後臓器障害の予防に有効 であると考えられる。このため種々の薬剤投与や 吸着除去による抗サイトカイン療法が研究されて おり，一部その臨床応用も報告されている。われ われは体外循環時の炎症性サイトカインの変動に 着目し, 蛋白分解酵素阻害剂の 1 つであるウリナ スタチン (urinary trypsin inhibitor：ミラクリ ッド®) が体外循環症例の炎症性サイトカインの 上昇を抑制し術後臓器障害の軽減に効果があるか どうかについて検討した。

\section{対象と方法}

1995 年 4 月から 1998 年 3 月までに体外循環下 に施行した待機的初回単独冠状動脈バイパス術症 例のうち体外循環時間が 100 分以上の 33 例を対 象とした。これらを 2 群に無作為に分類しウリナ スタチン投与群（UTI群， $n=16 ）$ と非投与群 (Control 群， $n=17$ ) とした。両群の患者背景は 表 1 のとおりで 2 群間にそれぞれ有意差を認めな かった。

体外循環はローラーポンプおよび膜型肺を使用 し軽度低体温下にて行った。 心筋保護法は continuous warm blood cardioplegia 法, intermittent cold blood cardioplegia 法, cold crystalloid cardioplegia 法のいずれかを用いた。UTI 群にはウリナスタチン 30 万単位を大動脈遮断直 後に Young 氏液につづいて冠状動脈内に投与し た。

検討項目はインターロイキン6（Interleukin-
6：IL-6)，インターロイキン 8（Interleukin-8： IL-8), 顆粒球エラスターゼ（polymorphonuclear leukocyte elastase: PMNE), GOT, GPT, 総ビリルビン (T-Bil), 血中尿素窒素 (BUN), 血中クレアチニン $(\mathrm{Cr})$, 動脈血酸素 分圧とした。大動脈遮断直前，大動脈遮断解除 5 分後，手術終了 6 時間後， 12 時間後， 18 時間後 に動脈血を採取し IL-6，IL-8，PMNEをそれぞ れ enzyme-linked immunosorbent assay （ELISA）法にて測定した。術後臓器障害は肝 臓，腎藏，肺について検討した。肝機能の指標に は術後 1 日目から 3 日目の GOT, GPT, T-Bil を，腎機能の指標には術後 1 日目から 3 日目の BUN，Cr を，肺酸素化能の指標には術後集中治 療室入室時, 術後 1 お び 2 日目の動脈血酸素分 圧/吸入気酸素濃度 $\left(\mathrm{PaO}_{2} / \mathrm{FIO}_{2}\right)$ をそれぞれ用 いた。

結果はすべて平均值士標準偏差で示した．統計 学的検討は 2 群間の比較には対応のない $t$ 検定を 用い，また相関関係はPearsonの相関関係を用 いて検定し，いずれも危険率 5\%未満を有意差あ りとした。

結果

\section{1. $\mathrm{IL}-6$}

Control 群では大動脈遮断直前 $7.6 \pm 6.2 \mathrm{pg} / \mathrm{dl}$ 加ら大動脈遮断解除 5 分後 $84.1 \pm 49.9 \mathrm{pg} / \mathrm{dl}$ と 高值を示した後, 手術 6 時間後 $32.0 \pm 28.3 \mathrm{pg} /$ $\mathrm{dl}$ ，手術 12 時間後 $20.2 \pm 18.3 \mathrm{pg} / \mathrm{dl}$ ，手術 18 時 間後 $18.9 \pm 16.1 \mathrm{pg} / \mathrm{dl}$ と漸減していった.UTI 群では大動脈遮断直前 $7.4 \pm 5.7 \mathrm{pg} / \mathrm{dl}$ から大動 

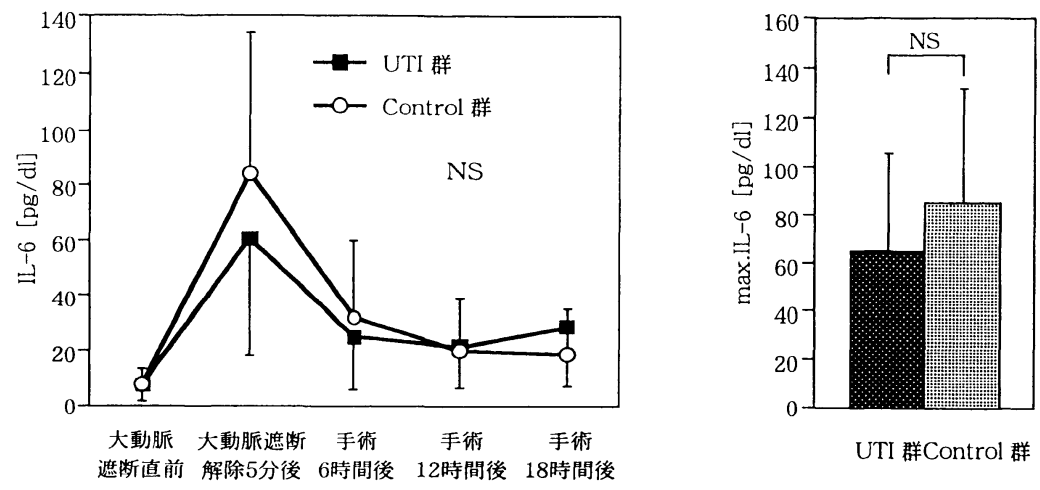

図 1 IL-6 の変動と最高值
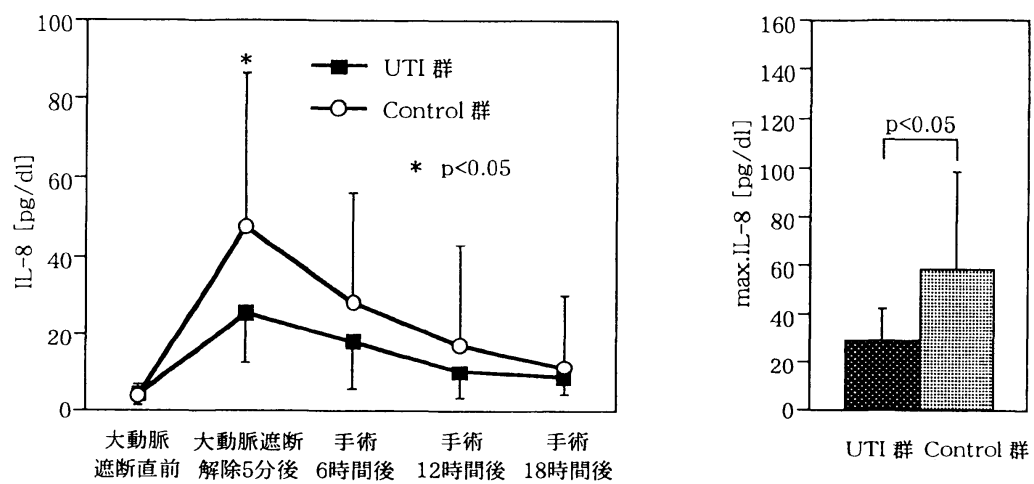

図 2 IL-8 の変動と最高値

脈遮断解除 5 分後 $60.5 \pm 42.6 \mathrm{pg} / \mathrm{dl}$ と高值を示 した後，それぞれ $24.9 \pm 19.2 ， 21.4 \pm 14.9$ ， $28.5 \pm 21.8 \mathrm{pg} / \mathrm{dl}$ と変動した。各測定地点で 2 群 間には有意差を認めなかった。また経過中の最高 值も 2 群間で有意差を認めなかった（図 1).

\section{2. $\mathrm{IL}-8$}

Control 群では大動脈遮断直前 $3.7 \pm 3.2 \mathrm{pg} / \mathrm{dl}$ から大動脈遮断解除 5 分後 $47.8 \pm 38.9 \mathrm{pg} / \mathrm{dl}$ と 高値を示した後，手術 6 時間後 $28.3 \pm 28.3 ， 12$ 時間後 $17.2 \pm 26.0 ， 18$ 時間後 $11.3 \pm 18.7 \mathrm{pg} / \mathrm{dl}$ と漸減していった。UTI群でもやはり大動脈遮 断直前 $4.1 \pm 2.8 \mathrm{pg} / \mathrm{dl}$ 加 大動脈遮断解除 5 分 後 $25.5 \pm 12.8 \mathrm{pg} / \mathrm{dl}$ と高值を示した後, 以後 $18.0 \pm 12.4 ， 10.1 \pm 7.1 ， 8.6 \pm 4.5 \mathrm{pg} / \mathrm{dl}$ と漸 減していった。大動脈遮断解除 5 分後にUTI 群 が有意に低值であった。経過中の最高值はControl 群 $58.4 \pm 40.0 \mathrm{pg} / \mathrm{dl}$ に対して UTI 群 $28.6 \pm$ $13.2 \mathrm{pg} / \mathrm{dl}$ が有意に低値を示した（図 2)。

\section{PMNE}

Control 群では大動脈遮断直前 $209 \pm 93 \mu \mathrm{g} / \mathrm{l}$ 加 大動脈遮断解除 5 分後 $1,740 \pm 1,060 \mu \mathrm{g} / l$ と 高值を示した後，手術 6 時間後 $1,034 \pm 728,12$ 時間後 $629 \pm 323 ， \quad 18$ 時間後 $745 \pm 1,226 \mu \mathrm{g} / l$ と 変動した。UTI 群では大動脈遮断直前 $357 \pm 596$ $\mu \mathrm{g} / l$ から大動脈遮断解除 5 分後 $1,422 \pm 694 \mu \mathrm{g} /$ $l$ と高值を示した後, 以後 $871 \pm 560,455 \pm$ 194， $568 \pm 535 \mu \mathrm{g} / l$ と変動した。手術 12 時間 後で UTI 群が Control 群に比べて低值をとる傾 向にあった。経過中の最高值は 2 群間で有意差を 認めなかった（図 3).

\section{4. 術後臓器障害}

GOT, GPT, T-Bil, BUN, Cr, $\mathrm{PaO}_{2} / \mathrm{FIO}_{2}$ の変動は表 2 のと㧍りであった。これらのうち術 後 2 日目の Cr と 2，3 日目の BUN でUTI 群が Control 群に比べ有意に低值を示した。

IL-6, IL-8, PMNE と術後藏器障害の指標と 

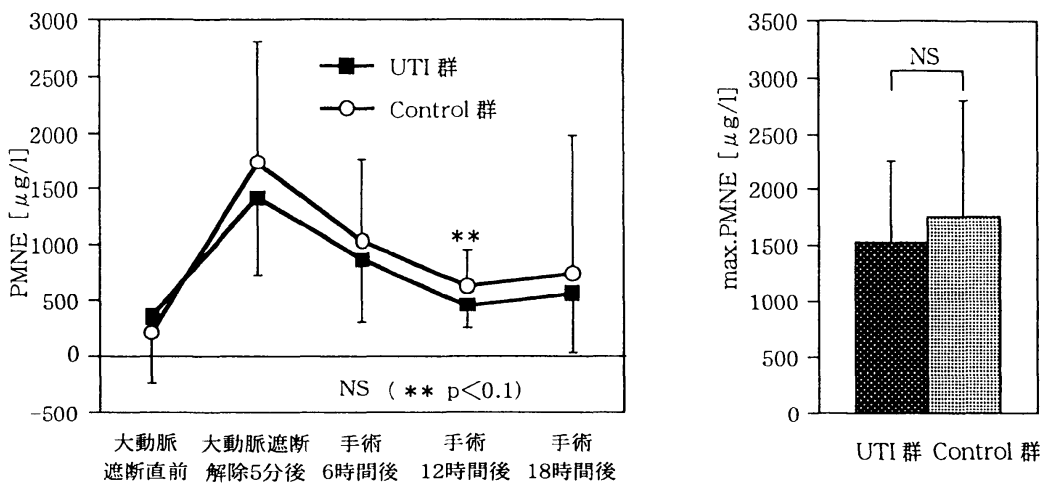

図 3 PMNE の変動と最高值

表 2 GOT, GPT, T-Bil, BUN, $\mathrm{Cr}, \mathrm{PaO}_{2} / \mathrm{FIO}_{2}$ の推移

\begin{tabular}{clcccc}
\hline & & 術前 & 術後1 日目 & 術後 2日目 & 術後 3日目 \\
\hline $\mathrm{GOT}$ & UTI 群 & $21.6 \pm 9.1$ & $114.9 \pm 145.4$ & $85.4 \pm 84.1$ & $44.5 \pm 33.3$ \\
$(\mathrm{IU} / l)$ & Control 群 & $24.6 \pm 12.8$ & $85.7 \pm 55.3$ & $74.1 \pm 50.8$ & $50.4 \pm 33.9$ \\
$\mathrm{GPT}$ & UTI 群 & $24.0 \pm 19.4$ & $27.7 \pm 22.5$ & $27.3 \pm 22.8$ & $24.0 \pm 17.2$ \\
$(\mathrm{IU} / l)$ & Control 群 & $23.7 \pm 16.4$ & $27.5 \pm 15.0$ & $25.5 \pm 10.9$ & $28.0 \pm 15.1$ \\
$\mathrm{~T}-\mathrm{Bil}$ & UTI 群 & $0.47 \pm 0.21$ & $1.74 \pm 1.47$ & $1.71 \pm 2.33$ & $1.77 \pm 2.99$ \\
$(\mathrm{mg} / \mathrm{dl})$ & Control 群 & $0.65 \pm 0.43$ & $1.17 \pm 0.45$ & $0.98 \pm 0.40$ & $0.94 \pm 0.46$ \\
$\mathrm{BUN}$ & UTI 群 & $17.0 \pm 7.1$ & $17.2 \pm 4.9$ & $18.0 \pm 6.4^{*}$ & $16.2 \pm 7.5^{*}$ \\
$(\mathrm{mg} / \mathrm{dl})$ & Control 群 & $16.6 \pm 4.8$ & $19.7 \pm 4.6$ & $27.2 \pm 10.9^{*}$ & $27.9 \pm 15.7^{*}$ \\
$\mathrm{Cr}$ & UTI 群 & $0.89 \pm 0.22$ & $0.90 \pm 0.22^{* *}$ & $0.80 \pm 0.22^{*}$ & $0.74 \pm 0.21^{* *}$ \\
$(\mathrm{mg} / \mathrm{dl})$ & Control 群 & $0.90 \pm 0.32$ & $1.21 \pm 0.56^{* *}$ & $1.36 \pm 0.94^{*}$ & $1.25 \pm 1.06^{* *}$ \\
\hline & & 術前 & ICU入室時 & 術後1日目 & 術後2 日目 \\
\hline $\mathrm{PaO}_{2} / \mathrm{FIO}_{2}$ & UTI 群 & $412.4 \pm 43.8$ & $314.4 \pm 104.2$ & $261.1 \pm 72.6$ & $242.1 \pm 70.1$ \\
& Control 群 & $406.2 \pm 50.5$ & $325.9 \pm 123.0$ & $300.9 \pm 104.7$ & $198.1 \pm 74.6$ \\
\hline
\end{tabular}

${ }^{*} p<0.05,{ }^{* *} p<0.10$.

表 3 IL-6, IL-8, PMNE と術後臓器機能との相関(有意差を認めたもののみ示す)

\begin{tabular}{|c|c|c|c|}
\hline & & 相関係数 & $p$ value \\
\hline IL-8 手術 6 時間後 & -BUN 術後 1 日目 & 0.397 & 0.029 \\
\hline IL-8 手術 6 時間後 & -BUN 術後 2 日目 & 0.400 & 0.028 \\
\hline IL-8 手術 12 時間後 & - $\mathrm{Cr}$ 術後 1 日目 & 0.382 & 0.036 \\
\hline IL-8 手術 12 時間後 & $-\mathrm{Cr}$ 術後 3 日目 & 0.362 & 0.049 \\
\hline IL-8 手術 12 時間後 & -BUN 術後 1 日目 & 0.437 & 0.015 \\
\hline IL-8 手術 12 時間後 & -BUN 術後 2 日目 & 0.428 & 0.017 \\
\hline PMNE 手術 18 時間後 & - $\mathrm{Cr}$ 術後 1 日目 & 0.685 & $<0.0001$ \\
\hline PMNE 手術 18 時間後 & $-\mathrm{Cr}$ 術後 2 日目 & 0.724 & $<0.0001$ \\
\hline PMNE 手術 18 時間後 & - $\mathrm{Cr}$ 術後 3 日日 & 0.765 & $<0.0001$ \\
\hline \multicolumn{2}{|c|}{ IL -8 大動脈遮断解除 5 分後 $-\mathrm{PaO}_{2} / \mathrm{FIO}_{2}$ ICU 入室時 } & -0.373 & 0.032 \\
\hline
\end{tabular}


したGOT, GPT, T-Bil, BUN, Cr, $\mathrm{PaO}_{2} /$ $\mathrm{FIO}_{2}$ との相関関係について検定した. 表 3 に示 すように IL-8，PMNE と BUN，Cr に有意な正 の相関を認めた。また大動脈遮断解除 5 分後の IL-8 と ICU 入室時 $\mathrm{PaO}_{2} / \mathrm{FIO}_{2}$ に負の相関を認 めた (表 3).

\section{考察}

今回の検討で UTI 群の大動脈遮断解除 5 分後 IL-8 值抒よび経過中最高 IL-8 值が Control 群に 比べて有意に低值を示し，腎機能の指標である BUN，CrがやはりUTI群において有意に低值 を示した。これは体外循環症例におけるウリナス タチン投与による抗 IL-8 効果と術後の臓器障 害，特に腎機能障害の予防効果を示唆するもので ある。また IL-8 やPMNEが術後の腎機能およ び肺酸素化能と相関を認めたことは，IL-8や PMNE の適切な抑制が術後臟器障害の予防に結 びつくであろうことを示している.

近年，外科学領域でも手術侵襲とこれによるサ イトカインの変動が注目され，サイトカインが手 術侵襲に対する生体反応に多大な役割を果たして いることが明らかにされてきだ゙. 体外循環はコ ントロールショックと称されるように生体に著し い侵襲を与えるため, 開心術症例に扔いても外科 的侵襲の例に漏れず種々のサイトカインが大きく 変動する ${ }^{4,5}$. 一方, 元来敗血症に対する臨床治 験の entry criteria を目的として提唱された SIRS は，最近では各種の侵襲による全身的な炎 症反応とされ, 多臟器不全状態の前段階および warning sign として注目されている。さらにこ の病態の本質が高サイトカイン血症にあると考え られるに至り，侵襲に対するサイトカインを含ん だ炎症性 mediatorへの対策の合理性，必要性， 重要性が理解されるようになってきた。そして過 度の高サイトカイン血症を適切に抑制することが 術後藏器障害や多藏器不全の予防につながると認 識されるようになった ${ }^{6}$.

今回検討した IL-6 は当初 B 細胞の最終分化段 階を誘導する因子として報告された。また IL-8 は主要な好中球活性化遊走制御因子であり，その 主な作用は組織への好中球の動員による炎症反応
の惹起である。いずれも単球，血管内皮細胞など 種々の細胞で産生され, 重症感染症, 敗血症, 手 術侵襲の重症度や程度，予後などと相関するとさ れている7,8). PMNE は IL-8や IL-6 に活性化さ れた好中球より放出され, 細胞障害, 臓器障害の 一因とされている。一部の疾患ではこれらの多寡 が病像を反映することが明らかにされている。体 外循環症例でも IL-6，IL-8，PMNE の変動は検 討されており，体外循環終了後高值をとり，体外 循環時間に相関することが報告されている ${ }^{9,10)}$. IL-6，IL-8 は血中で感度よく安定して測定でき るサイトカインとして外科的侵襲に対して鋭敏に 変動する生体反応のよい指標になりうると考えら れる。しかしサイトカインの特徵として 1 つのサ イトカインが複数の作用を有する pleiotrophy と 複数のサイトカインが同じ作用を有する redundancy があげられ，互いにネットワークを形成し ているため, 単一，一時点のサイトカインの多寡 を論じるのではなく，複数のサイトカインの推移 をとらえることも重要なことであると考えられ $3^{111}$.

これら IL-6 や IL-8 をはじめとする炎症性サ イトカインを抑制する抗サイトカイン療法として は，抗サイトカイン抗体（例：抗 $\mathrm{TNF}-\alpha$ 抗 体 ${ }^{12)}$ ), 可溶性受容体（例：可溶性 TNF 受容 体 $\left.{ }^{13)}\right)$, 受容体拮抗物質 (例：IL-1 受容体拮抗物 質 $\left.{ }^{14)}\right)$, 持続的血液濾過透析による吸着除 ${ }^{15)}$ 等が 報告されているものの，臨床応用され一般的に使 用しうるものはいまだ少ない。現在のところでは 以前よりその抗炎症性サイトカイン効果が推察, 報告されているステロイド16) や種々の蛋白分解 酵素阻害剤の投与 ${ }^{17)}$ が現実的である.今回われ われが検討したウリナスタチンは急性膵炎や急性 循環不全を保険適応としているヒ卜尿中に存在す る分子量 67,000 の糖蛋白質の多価酵素阻害剤で ある、種々のプロテアーゼを阻害するだけでな く，炎症性サイトカインである，IL-1，IL-6, IL-8, TNF- $\alpha$ や活性酸素などの産生を抑えると の報告がなされている ${ }^{18)}$. 今回われわれはその心 筋保護効果も期待して急性循環不全時の一日投与 量である 30 万単位を大動脈遮断開始直後に冠状 動脈内に one shot で投与した。既に報告してい 
るようにわれわれの検討では IL-6，I-8，PMNE については動脈血と冠静脈洞血でのそれぞれの濃 度が同值であり，これらによるウリナスタチンの 心筋保護効果の評価は行いえなかった ${ }^{19)}$. また, このシリーズにおいて使用した 3 つの心筋保護法 の違いで IL-6，IL-8，PMNE は有意差を認めな かった。以前より推測されているウリナスタチン の心筋保護効果については他のサイトカイン等に よる評価が必要と考えられる。加えてより有効な 抗サイトカイン療法として使用するためにはその 投与量および投与経路はさらなる検討が必要であ ろう。

体外循環後のサイトカインの変動をはじめとす る炎症反応は主に(1)人工心肺回路や空気等異物と 血液が接触すること, (2)心藏をはじめとする諸藏 器の虚血再灌流障害, の両者によると考えられ る ${ }^{19,20)}$. 特に前者については, 人工心肺が生体に 与える影響としていわゆる血液の denaturation という概念が以前より存在して抢り，サイトカイ ン産生，賦活化の大きな要因と考えられる。この 影響を考慮し本研究では検討症例を人工心肺時間 100 分以上のものとした。

今回の結果より体外循環症例におけるウリナス タチンの炎症性サイトカイン, 特に IL-8の抑制 効果が示唆された。しかしながら，体外循環症例 における抗サイトカイン療法の意味するところは 酵素阻害剤や抗サイトカイン抗体等の薬剤投与の みにあるわけではない。すなわち体外循環時間短 縮への努力や生体適合性人工心肺回路の開発など は，体外循環における炎症性サイトカイン産生を 直接抑制するものとして最も基礎的かつ有効な抗 サイトカイン療法と考えられ，抗サイトカイン効 果をもつ薬剤の開発と併せて炎症性サイトカイン の抑制扔よび臓器障害軽減のために必要不可欠で あることはいうまでもない。

\section{ま と め}

（1）体外循環下に冠状動脈バイパス術を施行 した症例について，IL-6，IL-8，PMNE を測定 し，ウリナスタチンの抗炎症性サイトカイン効果 と臓器障害予防効果について検討した。

（2）ウリナスタチン投与群の大動脈遮断解除
5 分後 IL-8 および経過中最高 IL-8 が Control 群 に比べて有意に低值を示し, 腎機能, 肺酸素化能 もよく保持された。

（3）IL-8，PMNE は腎機能，肺酸素化能と 相関し，これらの適正な抑制が術後臓器障害を軽 減すると推測された。

（4）体外循環時におけるウリナスタチン投与 は炎症性サイトカイン，特に IL-8 を適切に抑制 し, ひいては腎臓, 肺等の術後臓器障害を軽減せ しめることが示唆された.

\section{文献}

1) The ACCP/SCCM Consensus Conference Committee: Definitions for sepsis and organ failure and guidelines for the use of innovative therapies in sepsis. Crit. Care Med. 20: 864-874, 1992.

2) Bone, R.C.: Toward a theory regarding the pathogenesis of the systemic inflammatory response syndrome: What we do and do not know about cytokine regulation. Crit. Care Med. 24 : 163-172, 1996.

3) Roumen, R.H., Hendriks, T., van der VenJongekrijk, J. et al.: Cytokine patterns in patients after major vascular surgery, hemorrhagic shock, and severe blunt trauma. Relation with subsequent adult respiratory distress syndrome and multiple organ failure. Ann. Surg. 218: 769-776, 1993.

4）古永晃彦：体外循環時におけるサイトカインの 変動. 日胸外会誌 42：2200-2206, 1994.

5) Finn, A., Naik, S., Klein, N. et al. : Interleukin8 release and neutrophil degranulation after pediatric cardiopulmonary bypass. J. Thorac. Cardiovasc. Surg. 105: 234-241, 1993.

6）北村信哉, 平澤博之：重症患者に打ける systemic inflammatory response syndrome (SIRS)の転 帰扔よび病態の検討。日救急医会誌 $6: 662-672$, 1995.

7) Hack, C.E., De Groot, E.R., Felt-Bersma, R.J.F. et al. : Increased plasma levels of interleukin- 6 in sepsis. Blood 74 : 1704-1710, 1989.

8) Sakamoto, K., Arakawa, H., Mita, S. et al. : Elevation of circulating interleukin- 6 after surgery: Factors influencing the serum level. Cytokine 6 : 181-186, 1994.

9）山崎一也，相馬民太郎，小菅宇之ほか：体外循環 中の諸因子がサイトカインに及ぼす影響.人工臓 器 $26: 34-37,1997$.

10) Frering, B., Philip, I., Dehoux, M. et al. : Circu- 
lating cytokines in patients undergoing normothermic cardiopulmonary bypass. J. Thorac. Cardiovasc. Surg. 108: 636-641, 1994.

11) Kishimoto, T., Taga, T. and Akira, S.: Cytokine signal transduction. Cell 76:253-262, 1994.

12) Emerson, T.E., Lindsey, D.C., Jr., Jesmok, G.J. et al. : Efficacy of monoclonal antibody against tumor necrosis factor alpha in an endotoxemic baboon model. Circ. Shock 38: 75-84, 1992.

13) Van Zee, K.J., Kohno, T., Fischer, E. et al.: Tumor necrosis factor soluble receptors circulate during experimental and clinical inflammation and can protect against excessive tumor necrosis factor $\alpha$ in vitro and in vivo. Proc. Natl. Acad. Sci. U.S.A. 89 : 4845-4849, 1992.

14) Fischer, E., Marano, M., Van-Zee, K.J. et al. : Interleukin-1 receptor blockade improves survival and hemodynamic performance in Escher. ichia coli septic shock, but fails to alter host responses to sublethal endotoxemia. J. Clin. Invest. 89 : 1551-1557, 1992.

15) Bellomo, R., Tipping, P. and Boyce, N.: Continuous venovenous hemofiltration with dialysis removes cytokines from the circulation of septic patients. Crit. Care Med. 21: 522-526, 1993.

16) Teoh, K.H.T., Bradley, C.A., Gauldie, J. et al. : Steroid inhibition of cytokine-mediated vasodilation after warm heart surgery. Circulation 92: II-347-II-353, 1995.

17) Sawa, Y., Shimazaki, Y., Kadoba, K. et al.: Attenuation of cardiopulmonary bypassderived inflammatory reactions reduces myocardial reperfusion injury in cardiac operations. J. Thorac. Cardiovasc. Surg. 111 : 29-35, 1996.

18) Nakamura, H., Abe, S., Shibato, Y. et al.: Inhibition of neutrophil elastase-induced Interleukin-8 gene expression by urinary trypsin inhibitor in human bronchial epithelial cell. Int. Arch. Allergy Immunol. 112 : 157-162, 1997.

19) Karube, N., Adachi, R., Ichikawa, Y. et al.: Measurement of cytokine levels by coronary sinus blood sampling during cardiac surgery with cardiopulmonary bypass. ASAIO J. 42 : M787-M791, 1996.

20) Butler, J., Rocker, G.M., Westaby, S. et al. : Inflammatory response to cardiopulmonary bypass. Ann. Thorac. Surg. 55 : 552-559, 1993. 